\title{
Matinal, cultivar de sorgo blanco para el estado de Sinaloa*
}

\author{
Matinal, white sorghum cultivar for \\ the State of Sinaloa
}

\author{
Tomás Moreno Gallegos' ${ }^{1}$ Edith Oliva Cuevas Rodríguez ${ }^{2}$, Claudia María Melgoza Villagómez $^{2}$, Alfredo Loaiza Meza1 y Luis \\ Alberto Hernández Espinal ${ }^{1 \S}$
}

${ }^{1}$ Campo Experimental Valle de Culiacán-INIFAP. Carretera Culiacán-El Dorado, km 17.5. Municipio. C. P. 80000, Culiacán. Sinaloa, México. Tel. 01 6678461014. (moreno.tomas@inifap.gob.mx; loaiza.alfredo@inifap.gob.mx). ${ }^{2}$ Facultad Ciencias Químico Biológicas. Universidad Autónoma de Sinaloa. Blvd. de las Américas y Josefa O. de Domínguez, Ciudad Universitaria. C. P. 80040, Culiacán Rosales, Sinaloa, México. Tel. 01667 7594535. (edith.oliva@gmail.com; (cmelgozavillagomez@ gmail.com). ^Autor de correspondencia: luis_albertohernandez@yahoo.com.mx.

\section{Resumen}

La nueva variedad de sorgo Matinal fue desarrollado en el Campo Experimental Valle de Culiacán (CEVACU) del INIFAP y registrado con el número 2402-SOG-227-111012 en el Catálogo Nacional de Variedades Vegetales (CNVV) del SINCS de México. Esta variedad se adapta a las áreas productoras de sorgo para el estado de Sinaloa. Matinal es una variedad de ciclo vegetativo precoz, grano crema o ámbar y se recomienda para condiciones de riego y temporal. El rendimiento promedio de la variedad es de $2850 \mathrm{~kg} \mathrm{ha}^{-1} \mathrm{de}$ grano y $21900 \mathrm{~kg} \mathrm{ha}^{-1}$ de forraje verde, supera en promedio $3 \%$ y $9.5 \%$ respectivamente, el rendimiento de híbridos comerciales de compañías privadas, que se cultivan en la región bajo las mismas condiciones en temporal. Matinal tiene aceptable calidad bromatológica como los híbridos comerciales en el forraje, con $6.91 \%$ de proteína y $74.58 \%$ de digestibilidad, compitiendo favorablemente con los testigos con $7.5 \%$ y $66 \%$, respectivamente. Es tolerante a enfermedades en campo que se presentan en la región, como son: ergot (Claviceps africana), antracnosis (Colletotrichum graminicola), tizón de la panoja (Fusarium moniliforme) y pudrición carbonosa del tallo (Macrophomina phaseolina). Además Matinal presentó un tamaño de grano de 4.4, 4.2 y $2.8 \mathrm{~mm}$ de largo, ancho y grosor, respectivamente; y

\section{Abstract}

The new variety of sorghum Matinal was developed in the Culiacán Valley Experimental Field (CEVACU) of INIFAP and with the number 2402-SOG-227-111012 in the National Catalogue of Plant Varieties. This variety fits the sorghum producing areas of Sinaloa. Matinal is a variety of early growing season, grain or cream amber and is recommended for irrigated and rainfed conditions. The average yield is 2850 $\mathrm{kg} \mathrm{ha}^{-1}$ of grain and $21900 \mathrm{~kg} \mathrm{ha}^{-1}$ of green fodder, passing the average of $3 \%$ and $9.5 \%$ respectively, theyield of commercial hybrids of private companies, which are grown in the region under the same rainfed conditions. Matinal has an acceptable bromatological quality as the commercial hybrids in forage with $6.91 \%$ and $74.58 \%$ protein digestibility, competing favorably with the control with $7.5 \%$ and $66 \%$ respectively is tolerant field diseases that occur in the region, such as: ergot (Claviceps africana), anthracnose (Colletotrichum graminicola), head blight (Fusarium moniliforme) and Charcoal rot (Macrophomina phaseolina). Furthermore, Matinal presented a grain size of 4.4, 4.2 and 2.8 mm in length, width and thickness, respectively, and chemical composition of protein, lipid, ash and carbohydrates 13.9, 4.1, 1.8 and $80.2 \%$, respectively, so Matinal is proposed as a new potential for cultivation in the state of Sinaloa variety.

\footnotetext{
* Recibido: septiembre de 2013

Aceptado: febrero de 2014
} 
una composición química de proteínas, lípidos, cenizas y carbohidratos de 13.9, 4.1, 1.8 y $80.2 \%$, respectivamente; por lo que se propone a Matinal como una nueva variedad potencial para ser cultivada en el estado de Sinaloa.

Palabras clave: adaptación, grano, forraje, resistencia a enfermedades.

En México el sorgo (Sorghum bicolor L. Moench.) no se introduce en la alimentación directa del hombre, pero si en forma indirecta ya que el mexicano lo consume a través de alimentos de alto valor nutritivo, como son la carne de pollo, res y cerdo y el huevo principalmente (Gámez-González et al., 2010).

Entre los principales problemas que enfrenta el cultivo del sorgo en Sinaloa son la sequía, causada por la distribución errática de lluvias (de 450 a $600 \mathrm{~mm}$, durante el periodo de julio a noviembre), así como el escaso uso de prácticas de conservación y aprovechamiento de la humedad. En la entidad, $70 \%$ del sorgo se cultiva bajo condiciones de temporal y el resto en condiciones de riego (requerimiento hídrico del cultivo es de una lámina neta de $26.5 \mathrm{~cm}$ ), con rendimientos promedio de $1.35 \mathrm{tha}^{-1}$ y $6.83 \mathrm{tha}^{-1}$ de grano, respectivamente, y $7.94 \mathrm{t} \mathrm{ha}^{-1}$ y $13.60 \mathrm{t} \mathrm{ha}^{-1}$ de forraje verde, respectivamente (SIAP, 2013). Dado lo anterior, es necesario contar con genotipos más eficientes en el aprovechamiento de la humedad disponible del suelo, que sean de ciclo biológico corto o intermedio, adecuados a la distribución errática de la precipitación pluvial y tolerantes a enfermedades (Hernández-Espinal et al., 2010).

En el cultivo del sorgo las enfermedades generalmente son ocasionadas por hongos que provocan pérdidas en la producción de grano. Dentro de estas se encuentran: ergot, causada por Claviceps africana; antracnosis, causada por Colletotrichum graminicola; tizón de la panoja, causada por Fusarium moniliforme y pudrición carbonosa del tallo, causada por Macrophomina phaseolina (Velázquez et al., 2001; González et al., 2005; Williams-Alanís et al., 2009), cuya incidencia es mayor en plantas expuestas a largos periodos de sequía y altas temperaturas (Clafin y Giordan, 2002), condiciones que prevalecen normalmente en cultivos de sorgo de temporal localizados en el centro y sur de Sinaloa ocasionando reducción en el rendimiento y la calidad del grano hasta de $30 \%$, y si el estrés persiste durante el desarrollo, las pérdidas pueden llegar a 100\% (Edmunds, 1964; Williams-Alanís et al., 2004; Montes-García y DíazFranco, 2006). Se evaluó de forma visual, utilizando una
Keywords: adaptation, grain, forage, disease resistance.

In Mexico, sorghum (Sorghum bicolor L. Moench.) is not introduced in the direct supply of man, but indirectly as the Mexican through consuming highly nutritious foods, such as chicken, beef and mainly pork and egg (Gámez-González et al., 2010).

Among the main problems facing the cultivation of sorghum in Sinaloa are drought caused by the distribution of erratic rainfall (45 0 to $600 \mathrm{~mm}$ during the period from July to November), and the limited use of conservation practices and use of moisture. In the entity, $70 \%$ of sorghum is grown under rainfed conditions and the other under irrigation (water requirement of the crop is a net depth of $26.5 \mathrm{~cm}$ ), with average yields of $1.35 \mathrm{t} \mathrm{ha}^{-1}$ and $6.83 \mathrm{t} \mathrm{ha}^{-1}$ grain, respectively, and $7.94 \mathrm{tha}^{-1}$ and $13.60 \mathrm{tha}^{-1}$ green forage, respectively (SIAP, 2013). Given this, it is necessary to have more efficient genotypes in the use of available soil moisture, which are short or intermediate life cycle, appropriate to the erratic distribution of rainfall and disease tolerant precipitation (Hernández-Espinal et al., 2010).

In sorghum diseases are usually caused by fungi that cause losses in grain production. Among these are: ergot, caused by Claviceps africana, anthracnose, caused by Colletotrichum graminicola, head blight caused by Fusarium moniliforme and Charcoal rot caused by Macrophomina phaseolina (Velázquez et al., 2001; González et al., 2005; WilliamsAlanis et al., 2009), the incidence is higher in plants exposed to long periods of drought and high temperatures (Clafin and Giordan, 2002), conditions which normally prevail in sorghum crops temporarily located in the central and southern Sinaloa causing reduction on yield and grain quality to $30 \%$, and if the stress persists for the development or losses can reach 100\% (Edmunds, 1964; Williams-Alanis et al, 2004;. Montes-García and Díaz -Franco, 2006) was evaluated visually, using a scale of 1 to 5 where 1 is the most tolerant and 5 being the most susceptible. Provided The Matinal presented tolerance (level 2) in field to this complex amount of diseases, resulting similar assessment scale as reported by Williams-Alanis et al. (2012), which rated Matinal on a scale of 2.5 besides presenting greater adaptation to adverse conditions than commercial hybrids. Studies in Tamaulipas, Mexico reported in grain sorghum of genotype Matinal (a precocious Yellow) as the most tolerant to Macrophomina phaseolina, considering training for parents and hybrids tolerant to M. phaseolina (WilliamsAlanis et al., 2009). 
escala del 1 al 5 en donde 1 es el más tolerante y 5 es el más susceptible. La variedad Matinal presentó tolerancia (escala 2) en campo ante esta compleja variación de enfermedades, resultando similar en la escala de evaluación a lo reportado por Williams-Alanís et al. (2012), que califico a Matinal en una escala de 2.5, además de presentar mayor adaptación a condiciones adversas que los híbridos comerciales. En estudios realizados en Tamaulipas, México se reportó en sorgo para grano que el genotipo Matinal (amarillo precoz) como el más tolerante a Macrophomina phaseolina, considerándolo para la formación de progenitores e híbridos tolerantes a M. phaseolina (Williams-Alanís et al., 2009).

\section{Origen}

El Programa de Mejoramiento Genético de Sorgo del Campo Experimental Valle de Culiacán (CEVACU) del Instituto Nacional de Investigaciones Forestales, Agrícolas y Pecuarias (INIFAP), liberó la nueva variedad "Matinal" en 2012, la cual se obtuvo mediante recombinación genética y selección. El germoplasma que dio origen a esta variedad fue introducido durante 1986 al CEVACU, en Sinaloa, México, procedente del Instituto Internacional para el mejoramiento de Cultivos de los Trópicos Semi-Áridos (International Crops Research Institute for the SemiArid Tropics, ICRISAT), Hyderabad, India. Sus líneas progenitoras fueron una hembra androestéril y un restaurador masculino de la fertilidad, de genealogía ignota; a la cruza se le asignó la denominación AP (amarillo precoz).

La selección del material segregante de la cruzaAP, se inició a partir de la generación $\mathrm{F}_{2}$, mediante el método de surco por panoja o pedigrí durante siete generaciones. De esta manera se obtuvo la línea uniforme avanzada que dio origen a "Matinal", y cuyo pedigrí es:

\section{AP-1-M-2-1-2-1-M-M.}

De 1999 a 2008 esta variedad se evaluó en ensayos de rendimiento bajo condiciones de temporal o secano y riego, en varias localidades del estado de Sinaloa, México. Actualmente se encuentra inscrito en el Catálogo Nacional de Variedades Vegetales (CNVV) del SINCS con el número 2402-SOG-227-111012.

La descripción de la variedad de sorgo, se realizó utilizando los descriptores de la Unión de Productores y Obtentores de Variedades (UPOV), en el sur y centro de Sinaloa, donde el clima predominante es trópico seco, con precipitación

\section{Origin}

The Sorghum Breeding Program in the Experimental Field Culiacan (CEVACU) of the National Research Institute of Forestry, Agriculture and Livestock (INIFAP) released the new variety "Matinal" in 2012, which was obtained by genetic recombination and selection. Germplasm originated this variety was introduced in 1986 to CEVACU in Sinaloa, Mexico, from the International Crops Research Institute for the Semiarid Tropics ( ICRISAT). Hyderabad, India Its progenitor lines were a female - and male fertility restorer, of unknown descent, the crossing was assigned the AP(early yellow) designation.

The selection of the APmaterial segregating crosses, started from the $\mathrm{F}_{2}$ generation by the method of groove per panicle or pedigree for seven generations. Thus advanced uniform that gave rise to "Matinal" line was obtained, whose pedigree is:

AP-1-M-2-1-2-1-MM.

From 1999 to 2008 this variety was evaluated in tests of performance under rainfed and irrigation, in various locations around the State of Sinaloa, Mexico. Currently enrolled in the National Catalogue of Plant Varieties (CNVV) under number 2402-SOG-227-111012.

The description of the variety of sorghum was performed using the descriptors of the Union of Producers and Breeders (UPOV), and the southern and central Sinaloa, where the dry climate is predominantly tropical, with rainfall between 450 and $600 \mathrm{~mm}$, during the springsummer season in rainfed conditions, the Matinal variety behaves as cycle early vegetative, with 50-55 days to flowering and 95-100 days to harvest, with average heat requirements necessary units 676.31 to 1331.2 flowering and harvest, it has a height of $2.10 \mathrm{~m}$ plant, its leaves are light green color, medium texture, with anthocyanins, the stem has eight internodes at maturity and juice it has a soluble solids concentration of 13 to $15^{\circ} \mathrm{Brix}$, when plants have milky doughy. It has medium ears $(26 \mathrm{~cm})$, open with good excersion $(13 \mathrm{~cm})$ and flowering glumes without anthocyanins, the grain is cream or amber, circular and semi-flattened crystalline with testa and endosperm, and medium texture. The characteristics of plant height, panicle length and length of Matinal excersion during the autumn winter cycle, under irrigated conditions, tend to be lower than those presented in rainfed values. 
entre 450 y $600 \mathrm{~mm}$, durante el ciclo primavera-verano en condiciones de temporal o secano, la variedad Matinal se comporta como de ciclo vegetativo precoz, con 50 a 55 días a la floración y 95 a 100 días a la cosecha, con requerimientos necesarios de unidades calor promedio de 676.31 a la floración y 1331.2 a la cosecha, tiene una altura de planta de $2.10 \mathrm{~m}$, sus hojas son de color verde claro, de textura media, sin antocianinas; su tallo tiene ocho entrenudos a madurez y el jugo de éste tiene una concentración de sólidos solubles de 13 a $15^{\circ} \mathrm{Brix}$, cuando las plantas tienen el grano lechoso masoso. Cuenta con espigas medianas $(26 \mathrm{~cm})$, abiertas, con buena excersión $(13 \mathrm{~cm})$ y glumas sin antocianinas en floración; el grano es de color crema o ambar, de forma circular y semiaplanada, con testa y endospermo cristalinos, y de textura media. Las características de altura de planta, longitud de panoja y longitud de excersión de Matinal, durante el ciclo otoño invierno, en condiciones de riego, tienden a tener valores más bajos que los que presenta en temporal.

En evaluaciones realizadas bajo condiciones de temporal en la zona sur y centro de Sinaloa, Matinal mostró un comportamiento similar a los testigos comerciales. En ensayos de rendimiento realizados en un período de ocho años (1999 a 2006) durante el ciclo primavera-verano bajo temporal, Matinal demostró rendir en promedio $2850 \mathrm{~kg}$ ha $^{-1}$ de grano para superar en $3 \%$ al promedio de tres testigos comerciales (Cuadro 1).
In evaluations conducted under rainfed conditions in the south of Sinaloa, Matinal presented a similar behavior than the commercial controls. In yield tests conducted in a period of eight years (1999-2006) during the spring-summer cycle under rainfed, Matinal presented an average of $2850 \mathrm{~kg} \mathrm{ha}^{-1}$ of grain, overpassing in 3\% the average of three commercial controls (Table 1).

Williams-Alanis et al. (2009) and Montes-García et al. (2012) reported in grain yield, the variety Matinal (Early yellow) with an average yield of 1994 and $3555 \mathrm{~kg} \mathrm{ha}^{-1}$, respectively, which differs from the results obtained in the present study. It has been reported that the differences between the results of grain yield are due to several factors such as different weather conditions, drought, rainfall, temperature, planting dates and adaptation (Singh et al., 1990; Cloud et al., 1994).

During the spring-summer cycles 2003-2008, Matinal was evaluated for forage production in localities of San Ignacio, Elota, Mazatlán, Concordia, Cósala and Culiacán of the Sinaloa State, established under rainfed conditions, Matinal showed yield on average $21900 \mathrm{kgha}^{-1}$ of green fodder, $9.5 \%$ to exceed the average of the commercial control.

It also has the advantage of having a shorter growing season and lower requirement of heat units that commercial varieties and hybrids, on average 10 to 15 days to flowering and

Cuadro 1. Relación de genotipos de sorgo evaluados en rendimiento de grano (kg ha-1) cultivados en dos ambientes bajo temporal o secano en Sinaloa, México.

Table 1. Relationship of sorghum genotypes evaluated in grain yield $\left(\mathrm{kg} \mathrm{ha}^{-1}\right)$ grown in two environments under rainfed conditions in Sinaloa, Mexico.

\begin{tabular}{lccccccccc}
\hline Genotipo & PV 99 & PV 00 & PV 01 & PV 02 & PV 03 & PV 04 & PV 05 & PV 06 & $\bar{X}$ \\
\hline Matinal & $2980_{\mathrm{a}}$ & $2780_{\mathrm{a}}$ & $2860_{\mathrm{a}}$ & $2680_{\mathrm{a}}$ & $2960_{\mathrm{a}}$ & $2560_{\mathrm{ab}}$ & $3020_{\mathrm{a}}$ & $2960_{\mathrm{a}}$ & 2850 \\
Silomiel* & $2830_{\mathrm{a}}$ & $2730_{\mathrm{a}}$ & $2940_{\mathrm{a}}$ & $2730_{\mathrm{a}}$ & $2850_{\mathrm{a}}$ & $2260_{\mathrm{b}}$ & $2890_{\mathrm{a}}$ & $2930_{\mathrm{a}}$ & 2770 \\
Cow Vittles* & $2760_{\mathrm{a}}$ & $2680_{\mathrm{a}}$ & $2810_{\mathrm{a}}$ & $2790_{\mathrm{a}}$ & $2450_{\mathrm{b}}$ & $2820_{\mathrm{a}}$ & $2790_{\mathrm{a}}$ & $2580_{\mathrm{a}}$ & 2710 \\
Hegary* & $2780_{\mathrm{a}}$ & $2690_{\mathrm{a}}$ & $2800_{\mathrm{a}}$ & $2680_{\mathrm{a}}$ & $2890_{\mathrm{a}}$ & $2960_{\mathrm{a}}$ & $2870_{\mathrm{a}}$ & $2810_{\mathrm{a}}$ & 2810 \\
Media & 2837.5 & 2720 & 2852.5 & 2720 & 2787.5 & 2650 & 2892.5 & 2820 & 2785 \\
CV $(\%)$ & 7.48 & 8.39 & 7.12 & 8.03 & 5.77 & 8.05 & 4.59 & 7.42 & \\
DMS $_{0.05}$ & 399.86 & 429.97 & 382.87 & 411.54 & 303.31 & 401.85 & 250.14 & 394.28 & \\
\hline
\end{tabular}

$*=$ testigos comerciales; $\mathrm{PV}=$ primavera-verano, $\mathrm{CV}=$ coeficiente de variación. Medias con letras iguales son estadísticamente iguales.

Williams-Alanís et al. (2009) y Montes-García et al. (2012) reportan, en rendimiento de grano, la variedad Matinal (Amarillo precoz) con un rendimiento promedio de 1994 y $3555 \mathrm{~kg} \mathrm{ha}^{-1}$ respectivamente, lo cual difiere con los resultados obtenidos en el presente estudio. Se ha reportado
201.95 heat units. This feature gives advantage to planting in rainfed and irrigated conditions, as it requires less moisture to complete their development, thereby evading drought caused by lack of rainfall or irrigation water shortages. 
que las diferencias entre los resultados de rendimiento de grano se deben a varios factores como diferentes condiciones climáticas, sequía, precipitación pluvial, temperatura, fechas desiembrayadaptación(Singhetal., 1990; Cloud etal., 1994).

Durante los ciclos primavera- verano 2003 a 2008, Matinal se evaluó la producción de forraje en las localidades de San Ignacio, Elota, Mazatlán, Concordia, Cósala y Culiacán del estado de Sinaloa, establecidos bajo temporal, Matinal demostró rendir en promedio $21900 \mathrm{kgha}^{-1}$ de forraje verde, para superar en $9.5 \%$ al promedio del testigo comercial.

Además, tiene la ventaja de tener un ciclo vegetativo más corto y menor requerimiento de unidades calor que las variedades e híbridos comerciales, en promedio de 10 a 15 días a la floración y 201.95 unidades calor. Esta característica le confiere ventaja para la siembra en condiciones de temporal y riego, ya que requiere demenos humedad para completar su desarrollo, evadiendo con ello la sequía originada por falta de precipitación pluvial o por escasez de agua de riego.

La calidad bromatológica del forraje bajo riego, durante los ciclo otoño- invierno 2003 a 2008, fue de $74.58 \%$ de digestibilidady $6.91 \%$ de proteína, superando en digestibilidad al testigo comercial con 8.58 puntos porcentuales y siendo ligeramente rebasada por éste en contenido de proteína, con 0.59 puntos porcentuales. El nivel de rendimiento y lacalidad bromatológica de forraje ubica a la variedad Matinal como un material de doble propósito, cuyo potencial puede ser destinado al ensilaje; actividad estratégica de conservación de forraje que coadyuva en la solución del principal problema de la ganadería de temporal en Sinaloa: la falta de forraje durante la época seca del año (Hernández-Espinal et al., 2010).

Por otro lado, en un análisis físico y químico de los granos de sorgo se encontró que las dimensiones físicas de esta variedad (largo, ancho y grosor) fueron de 4.4, 4.2 y 2.8 $\mathrm{mm}$, respectivamente; se ha reportado que los granos de sorgo típicamente son redondos, aunque la mayoría tiene una parte aplanada (Reicher et al., 1988); en variedades e híbridos comerciales se ha mostrado que los granos de sorgo tienen en promedio valores de 4, 2.5 y $2 \mathrm{~mm}$ de largo, ancho y grosor, respectivamente (Rooney y Serna-Saldívar, 2000). Mientras tanto, el peso de 1000 granos de la variedad Matinal fue de $36 \pm 0.11 \mathrm{~g}$.

Debido a la diversidad genética, los granos de sorgo pueden variar de tamaño y forma, investigaciones de Rooney y SernaSaldivar (2000) han reportado que el peso de 1000 granos de
The bromatological irrigated forage quality during the autumn-winter cycle 2003 to 2008, was $74.58 \%$ and $6.91 \%$ of digestible protein digestibility surpassing the commercial control with 8.58 percentage points and being slightly overwhelmed by it in protein content with 0.59 percentage points. The level of yield and quality of forage bromatological places the Matinal variety as a dual purpose material whose potential is intended for silage; strategic forage conservation activity that contributes to the solution of the main problem of livestock in Sinaloa: lack of fodder during the dry season (Hernández-Espinal et al., 2010.).

On the other hand, in a physical and chemical analysis of sorghum grains was found that the physical dimensions of this variety (length, width and thickness) were 4.4, 4.2 and $2.8 \mathrm{~mm}$, respectively, it has been reported that sorghum grains typically are round, but most have a flattened portion (Reicher et al., 1988) varieties commercial hybrids have been shown to sorghum grains have an average value of 4 , 2.5 and $2 \mathrm{~mm}$ in length, width and thickness respectively (Rooney and Serna-Saldivar, 2000). Meanwhile, the weight of 1000 Beads variety Matinal was $36 \pm 0.11 \mathrm{~g}$.

Because of the genetic diversity, sorghum grains can vary in size and shape, investigations Serna-Saldivar and Rooney (2000) reported that the weight of 1000 -grain sorghum can vary from 30 to $80 \mathrm{~g}$ depending on cultivar and climatic conditions where they were grown. Also introduced a test weight of $879.9 \pm 5.10 \mathrm{~g} / \mathrm{hL}$ above those reported by PérezCarrillo and Serna-Saldivar (2007) (765.2 g/hL) for regular white sorghum grains.

The chemical composition Matinal's grains showed a percentage of protein, fat, ash and carbohydrate 13.9, 4.1, 1.8 and $80.2 \%$, respectively, several studies have reported that sorghum proteins containing a range of 10.4 to $12.41 \%$, and lipid ranges from 3.1 to $3.6 \%$ and ranges from 1.5 to $1.7 \%$ ash (Rooney and Serna-Saldivar, 2000). As with forage agronomic traits and physical and chemical characteristics of sorghum grains, Matinal is proposed as a new potential for cultivation in the state of Sinaloa variety.

Due to the recent demand nationwide genotypes that are drought tolerant and early growing seasons, INIFAP available to the public of seed genotyping "Matinal". Agricultural producers, rural production companies and seed companies interested in this material may go to Experimental Field of Culiacán and apply for the seeds needed. Besides 
sorgo puede variar de 30 a $80 \mathrm{~g}$ dependiendo del cultivar y de las condiciones climáticas donde fueron cultivados. Además, presentó un peso hectolítrico de $879.9 \pm 5.10 \mathrm{~g} / \mathrm{hL}$ por arriba de lo reportado por Pérez-Carrillo y Serna-Saldivar (2007) $(765.2 \mathrm{~g} / \mathrm{hL})$ para granos de sorgo blanco regular.

La composición química de los granos de sorgo Matinal mostró un porcentaje de contenido de proteínas, lípidos, cenizas y carbohidratos de $13.9,4.1,1.8$ y $80.2 \%$, respectivamente, diversas investigaciones han reportado que el sorgo contiene un rango de proteínas de 10.4 a $12.41 \%$, así como rangos de lípidos de 3.1 a 3.6\% y rangos de 1.5 a $1.7 \%$ de cenizas (Rooney y Serna-Saldivar, 2000). Por lo que, con las características agronómicas del forraje y las características físicas y químicas de los granos de sorgo, se propone a Matinal como una nueva variedad potencial para ser cultivada en el estado de Sinaloa.

Debido a la reciente demanda a nivel nacional de genotipos que sean de ciclos vegetativos precoces y tolerantes a sequía, el INIFAP pone a disposición del público semilla del genotipo "Matinal”. Los productores agropecuarios, las sociedades de producción rural y las compañías de semillas interesadas en este material, pueden acudir al Campo Experimental Valle de Culiacán y presentar su solicitud de necesidades de semilla. Además de tener la ventaja de que la semilla es más barata, los agricultores pueden producir su propia semilla reduciendo con ello, de manera significativa los costos de producción.

\section{Agradecimientos}

Al apoyo financiero proporcionado por la Fundación Produce Sinaloa, A. C. a través del proyecto. Núm. 2055985A titulado: Formación de variedades e híbridos de sorgo para temporal y riego en el estado de Sinaloa y a la Universidad Autónoma de Sinaloa por el apoyo otorgado a través de los Proyectos PROFAPI-2012 para la realización de una parte de este proyecto.

\section{Literatura citada}

Cloud, G. and J. Rupe. 1994. Influence of nitrogen, plant growth stage and environment on charcoal rot of grain sorghum caused by Macrophomina phaseolina (Tassi) Goid. Plant and Soil 158:203-210. having the advantage that the seed is cheaper, farmers can produce their own seed thereby reducing, significantly production costs.

\section{End of the English version}

Clafin, L. E. and Giorda, L. M. 2002. Stalk rots of sorghum. In: Leslie, J. F. (Ed.). Sorghum and Millet Diseases. Chapter 33. Iowa State Press. Ames, USA. 504 p.

Edmunds, L. K. 1964. Combined relation of plant maturity, temperature, and soil moisture to charcoal stalk rot development in grain sorghum. Phytopathology 54:514-517.

Gámez-González, H.; Moreno, L. S.; Zavala, G. F.; Morales, R. I. y Damián, H. M A. 2010. El sorgo: Contribuciones al conocimiento de su fisiología. Primera edición. Universidad Autónoma de Nuevo León. 2 p.

González, R.; Ávila, J. y Pieruzzini, N.2005. Manejo de las principales enfermedades del sorgo en el estado Portuguesa. Aspectos Fitosanitarios 6:29-32.

Hernández-Espinal, L. A.; Moreno, G. T.; Loaiza, M. A. y Reyes, J. J. E. 2010. Gavatero-203, nueva variedad de sorgo forrajero para el estado de Sinaloa. Rev. Mex. Cienc. Agríc. 1(5):727-731.

Montes-García, N. y Díaz Franco, A. 2006. Fitopatología. In: Rodríguez del Bosque, L. A. (Ed.). Campo Experimental Río Bravo: 50 Años de Investigación Agropecuaria en el Norte de Tamaulipas. Historia, logros y retos. 192-213 pp.

Montes-García N.; Williams-Alanís, H.; Moreno-Gallegos, T.; CisnerosLópez, M. E. y Pecina-Quintero V. 2012. Rb-paloma variedad de sorgo blanco para producción de grano y forraje. Rev. Fitotec. Mex. 35(2):185-187.

Perez-Carrillo, E. and Serna-Saldívar, O. 2007. Effect of preotease treatment before hydrolisis with -amylasa on the rate of starch and protein hydrolysis of maize, whole sorghum and decorticated sorghum. Cereal Chem. 607-613.

Reichert, R.; Mwararu,M. and Mukuru, S. 1988. Characterization of colored grain sorghum lines and identification of high tannin lines with good dehulling characteristics. Cereal Chem. 65:165-170.

Rooney, L. W. and Serna-Saldivar, S. O. 2000. Sorghum. In: Kulp, K. and Ponte, J. G. Jr. (Eds.) Handbook of cereal science and technology. $2^{\text {nd }}$ (Ed.). New York: Marcel D. 149-176 pp.

Servicio de Información y Estadística Agroalimentaria y Pesquera (SIAP). 2013.Anuarioestadísticodelaproducciónagrícola2011 enMéxico. El cultivo de sorgo. SAGARPA. URL: http://www.siap.gob.mx.

Singh, S. K.; Nene, Y. L. and Reddy, M. V. 1990. Influence of cropping systems on Macrophomina phaseolina populations in soil. Plant Dis. 74:812-814.

Velázquez, V. R.; Narro, S. J. y Torres, M. H. 2001. Diseminación inicial del cornezuelo (Claviceps africana) de sorgo en México. Rev. Mex. Fitopatol. 19:100-103.

Williams-Alanís, H.; Zavala-García, F.; Martínez-Hernández, R.; Rangel-Estrada, S. E. y Machuca-Orta, I. 2004. Reacción a Macrophomina phaseolina (Tassi) Goid de híbridos comerciales y experimentales de Sorgo [Sorghum bicolor (L.) Moench.] para grano. Rev. Mex. Fitopatol. 22:216-222.

Williams-Alanís, H.; Pecina-Quintero, V.; Montes-García, N.; PalaciosVelarde, O.; Arcos-Cavazos, G. y Vidal-Martínez, V. A. 2009 Reacción de variedades de sorgo [Sorghum bicolor (L.)Moench.] para grano a Macrophomina phaseolina (Tassi) Goid. Rev. Mex. Fitopatol. 27:148-155. 